\title{
Association of oxidative stress and DNA damage with grafting time in patients with multiple myeloma and lymphoma submitted to autologous hematopoietic stem cell transplantation
}

\author{
Thayna Nogueira Dos Santos ${ }^{1 *}$, Fernando Barroso Duarte ${ }^{2 *}$, Pedro Aurio Maia Filho ${ }^{1}$, Talyta Ellen De Jesus Dos Santos ${ }^{3}$, \\ Maritza Cavalcante Barbosa ${ }^{3}$, Tarcísio Paulo De Almeida Filho ${ }^{1}$, Bruno Coelho Cavalcanti ${ }^{4}$, Paulo Roberto Leitão De \\ Vasconcelos ${ }^{5}$, Luana Leticia Dutra ${ }^{1}$, Germison Silva Lopes ${ }^{2}$, Franciclea Oliveira Costa ${ }^{6}$, João Paulo Vasconcelos Leitão², \\ Jacques Kaufman², Beatriz Stella Pitombeira Araújo², Karine Sampaio Nunes Barroso², Romélia Pinheiro Gonçalves Lemes ${ }^{7}$. \\ ${ }^{1}$ Master's Degree in Pathology, Laboratory of Hemoglobinopathy Research and Genetics of Hematologic Diseases, Universidade Federal do Ceará, Brazil \\ ${ }^{2}$ Hematologist Physician at the Hematopoietic Cell Transplantation Service - Hospital Universitário Walter Cantídio, Universidade Federal do Ceará, Brazil \\ ${ }^{3}$ Master's Degree in Pharmaceutical Sciences, Laboratory of Hemoglobinopathy Research and Genetics of Hematologic Diseases, Universidade Federal do Ceará, Brazil \\ Ph.D. in Pharmacology, Department of Physiology and Pharmacology, Universidade Federal do Ceará, Brazil \\ ${ }^{5} \mathrm{Ph} . \mathrm{D}$. in General Surgery, Department of Surgery, Universidade Federal do Ceará, Brazil \\ ${ }^{6}$ Nurse at the Hematopoietic Cell Transplantation Service - Hospital Universitário Walter Cantídio, Universidade Federal do Ceará, Brazil \\ 'Ph.D. and Full Professor of Universidade Federal do Ceará- Department of Clinical and Toxicological Analyses; Laboratory of Hemoglobinopathy Research and Genetics of Hematologic Diseases, Universidade Federal do Ceará, Brazil.
}

\begin{abstract}
Hematopoietic Cell Transplantation Service Hospital Universitário Walter Cantídio and Laboratório de Pesquisa em Hemoglobinopatias e Genética das Doenças Hematológicas, Universidade Federal do Ceará, Brazil

*Correspondence to: Rua Capitão Francisco Pedro, 1290 60430-370, Rodolfo Teófilo

The aim of the study was to investigate the association between oxidative stress and DNA damage with grafting time in patients submitted to autologous hematopoietic stem-cell transplantation (HSCT). The study included 37 patients submitted to autologous HSCT diagnosed with Multiple Myeloma (MM) and lymphoma (Hodgkin's and non-Hodgkin's). Biomarkers of oxidative stress and DNA damage index (DI) were performed at baseline (pre-CR) of the disease and during the conditioning regimen (CR), one day after the HSCT, ten days after HSCT and twenty days after HSCT, as well as in the control group consisting of 30 healthy individuals. The outcomes showed that both groups of patients had an hyperoxidative state with high DI when compared to baseline and to the control group and that the CR exacerbated this condition. However, after the follow-up period of the study, this picture was re-established to the baseline levels of each pathology. The study patients with MM showed a mean grafting time of 10.75 days ( 8 to 13 days), with 10.15 days ( 8 to 15 days) for the lymphoma patients. In patients with MM, there was a negative correlation between the grafting time and the basal levels of GPx $(r=-0.54 ; p=0.034)$, indicating that lower levels of this important enzyme are associated with a longer grafting time. For the DI, the correlation was a positive one $(r=0.529 ; p=0.030)$. In the group with lymphoma, it was observed that the basal levels of NOx were positively correlated with grafting time $(r=0.4664, p=0.032)$. The data indicate the potential of these biomarkers as predictors of toxicity and grafting time in patients with MM and Lymphomas submitted to autologous HSCT.
\end{abstract} Fortaleza, Ceará, Brasil nutriquimio@uol.com.br

http://dx.doi.org/10.1590/1806-9282.62.Suppl1.39
Keywords: Autologous hematopoietic stem-cell transplantation; Oxidative stress; DNA damage; Multiple myeloma; Lymphoma.

\section{INTRODUCTION}

The conditioning regimen with high-dose chemotherapy used for autologous stem cell transplantation (HSCT) has been associated with increased production of reactive oxygen species (ROS) and depletion of important components of the antioxidant system ${ }^{1-4}$. Considering that ROS affect cell cycle progression and signaling of growth fac- tors in several cell types, including stem cells and hematopoietic progenitors, oxidative stress has been reported as one of the proposed mechanisms to explain the damage to several tissues after $\mathrm{HSCT}^{5,6}$.

The aim of the study was to investigate the association between oxidative stress and DNA damage with the grafting time in patients undergoing HSCT. 


\section{Methods}

The study included 37 patients submitted to autologous HSCT at Hospital Universitário Walter Cantídio (HUWC) in Fortaleza, Ceará, in 2013. Patients were stratified into two groups: Myeloma, consisting of patients diagnosed with MM ( $\mathrm{n}=17)$, and Lymphomas $(\mathrm{n}=20)$, consisting of patients with Hodgkin's lymphoma $(\mathrm{n}=10)$ and non-Hodgkin's lymphoma $(\mathrm{n}=10)$. The control group consisted of 30 healthy subjects with matched age and gender according to the group of patients. Individuals using antioxidants, smokers, those who consumed alcohol, were infected with hepatitis, HIV or HTLV virus were excluded from the study.

The study was approved by the Research Ethics Committee of HUWC under protocol number 08022912.8.0000.5045. All participants in the study agreed to participate by signing the free and informed consent form.

\section{Autologous HSCT}

The autologous HSCT procedure followed the standard protocol of the institution. The mobilization of stem cells was performed with granulocyte colony stimulating factor (G-CSF) at a dose of $10-16 \mathrm{mg} / \mathrm{kg} /$ day. Subsequently, CD34+ cells were collected and cryopreserved for the HSCT. The patients were submitted to the $\mathrm{CR}$ (conditioning regimen) according to the underlying disease: the Myeloma group received melphalan $\left(200 \mathrm{mg} / \mathrm{m}^{2}\right)$ and the Lymphoma group received polychemotherapy, comprising carmustine $300 \mathrm{mg} / \mathrm{m}^{2}$, etoposide $600 \mathrm{mg} / \mathrm{m}^{2}$, cytarabine $1600 \mathrm{mg} / \mathrm{m}^{2}$, cyclophosphamide $140 \mathrm{mg} / \mathrm{m}^{2}$ and mesna $168 \mathrm{mg} / \mathrm{m}^{2}$ (for HL patients) and carmustine $300 \mathrm{mg} / \mathrm{m}^{2}$, etoposide $600 \mathrm{mg} / \mathrm{m}^{2}$, cytarabine $1600 \mathrm{mg} / \mathrm{m}^{2}$ and melphalan $140 \mathrm{mg} / \mathrm{m}^{2}$ for the other patients.

Peripheral blood samples were collected for determination of the parameters analyzed during the following moments: baseline or pre-CR; during the $\mathrm{CR}$ (the last day on which the patient received chemotherapy: D-1); 1 day after autologous HSCT (D+1); 10 days after autologous HSCT $(\mathrm{D}+10)$ and 20 days after autologous HSCT $(\mathrm{D}+20)$. The Pre-CR time was considered as the moment that reflects the patient's baseline condition before the autologous HSCT intervention.

\section{Oxidative StRESS ANALYSIS}

Malondialdehyde (MDA), a lipid peroxidation product, was determined by its reaction with thiobarbituric acid (TBARS) by spectrophotometry at $532-535 \mathrm{~nm}^{7}$.

Nitric oxide levels were determined by the concentration of nitrite/nitrate (NOx) according to the method by
Green et al. (1981) using the spectrophotometric method ${ }^{8}$. The reading was performed through absorbance at $560 \mathrm{~nm}$.

The activity of the catalase (CAT) enzyme was measured in hemolysates by monitoring the $\mathrm{H}_{2} \mathrm{O}_{2}$ reduction rate at $240 \mathrm{~nm}$ in a spectrophotometer. The enzymatic activity was expressed as $\mathrm{U} / \mathrm{L}^{9}$.

The activity of the glutathione peroxidase (GPx) and superoxide dismutase (SOD) enzymes was determined in hemolysates using the Ransel Glutathione Peroxidase ${ }^{\circledR}$ and RANSOD $^{\circledR}$ (RANDOX BRAZIL Ltd.) kits, respectively, according to the manufacturer's specifications.

\section{DNA damage Assessment - the Comet assaY}

The test was performed according to Singh et al $(1988)^{10}$, by fixing leukocytes to a slide with low meltingpoint agarose, subsequently submitted to electrophoresis. The DNA damage index (DI) was determined by fragmented DNA content after ethidium bromide staining.

\section{Statistical ANAlysis}

The results obtained in the performed analyses were tabulated and plotted using the GraphPadPrism 5.0 program, which was used for statistical analysis. The differences between the means of the groups were verified by analysis of variance (ANOVA TWO-WAY) followed by Tukey's post-test. Statistically significant differences were considered with $\mathrm{p}<0.05$.

\section{RESULTS}

Figure 1 shows the data of oxidative stress parameters at all times of HSCT.

Patients with $\mathrm{MM}$ and lymphoma had significantly high basal MDA levels when compared with the control group at all times when peripheral blood collection was performed, with significant differences according to the type of patient diagnosis after the conditioning phase, which implies that the type of approach or the patient's own clinical condition greatly influences MDA increase after the $\mathrm{CR}$.

Regarding NOx analysis, it was observed that this oxidative stress parameter is increased in patients submitted to HSCT. We emphasize that on $\mathrm{D}+10$ to $\mathrm{D}+20$ a trend was observed in patients with lymphoma of having higher NOx values than patients with myeloma.

When comparing the SOD activity, this enzyme showed significantly reduced activity at baseline (pre-CR) in the control group. At the other times, a tendency to having lower values of this marker in patients diagnosed with myeloma was observed, when compared to patients with lymphoma. 
Catalase showed an increase profile at baseline (pre-CR), showing significant elevation when compared to the means in the control group. At other times, lymphoma patients tended to have lower values of this enzyme activity when compared to patients diagnosed with myeloma.

Regarding the times of HSCT, the CR was able to raise the MDA levels $(\mathrm{p}<0.01)$ and decrease the SOD and CAT activities in both groups of patients. Twenty days after HSCT $(\mathrm{D}+20)$, we observed that the MDA levels were restored to the baseline levels of each pathology; however, they were still higher than in the control group ( $\mathrm{p}<0.0001)$. At times $\mathrm{D}+1$, $\mathrm{D}+10$ and $\mathrm{D}+20$, MDA levels in the Lymphoma group were significantly elevated compared to the MM group $(p<0.05)$.

The CAT activity was re-established at time $\mathrm{D}+1$ for the Myeloma group and time $\mathrm{D}+10$ for the lymphoma group to higher levels than those in the control group $(\mathrm{p}<0.0001)$. The SOD activity was restored to levels similar to those in the control group at time $\mathrm{D}+20$ for the two groups of patients.
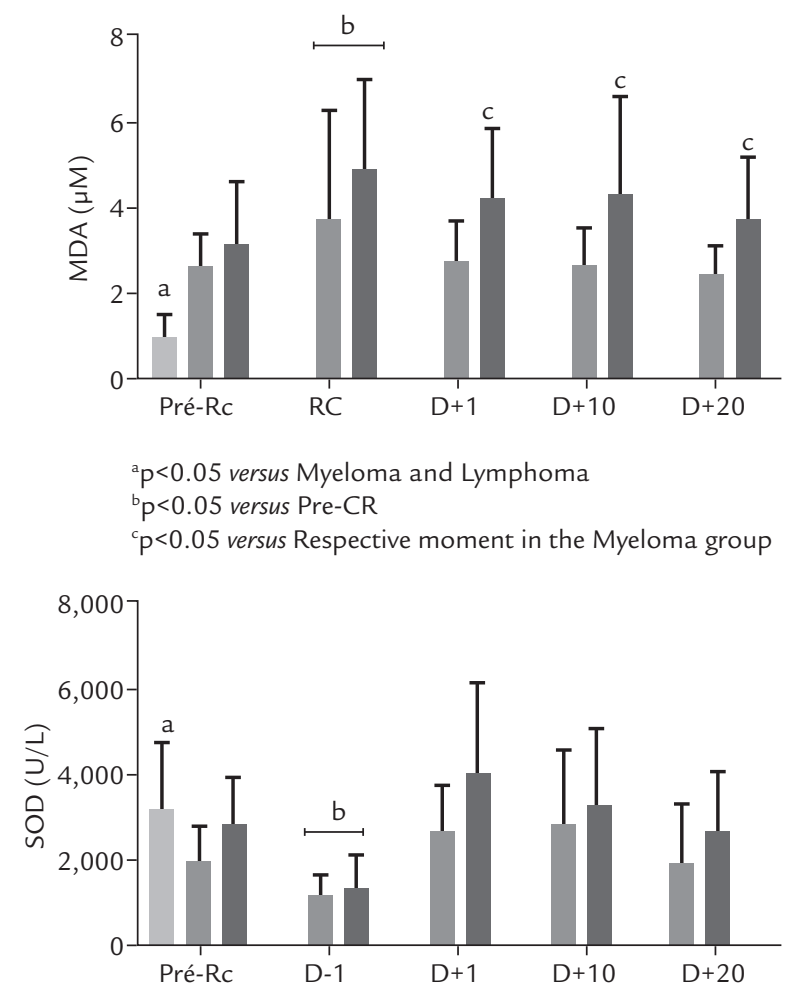

${ }^{\mathrm{a}} \mathrm{p}<0.05$ versus Mieloma

${ }^{\mathrm{b}} \mathrm{p}<0.05$ versus Pre-CR, D+1, D+10 and $\mathrm{D}+20$ of the respective groups
There was no statistically significant difference between the NOx levels and GPx activity at the different times of HSCT.

Patients with myeloma and lymphoma showed significantly higher DI than the control group. It was also observed that the $\mathrm{CR}$ was able to increase the DI in the two groups of patients $(\mathrm{p}<0.05)$; however, one day after HSCT $(D+1)$, these values decreased significantly, resembling those observed at baseline, twenty days after HSCT (D+20).

The mean grafting time in patients with $\mathrm{MM}$ was 10.75 days, ranging from 8 to 13 days and 10.15 days for the lymphoma group, ranging from 8 to 15 days. The correlation analysis between the oxidative stress parameters and DI with grafting time after HSCT showed that for patients with MM, there was a negative correlation between the grafting time and the basal levels of GPx $(r=-0.54$; $\mathrm{p}=0.034)$. For the DI, the correlation was positive $(\mathrm{r}=0.529 ; \mathrm{p}=0.030)$. In the group with lymphoma, it was

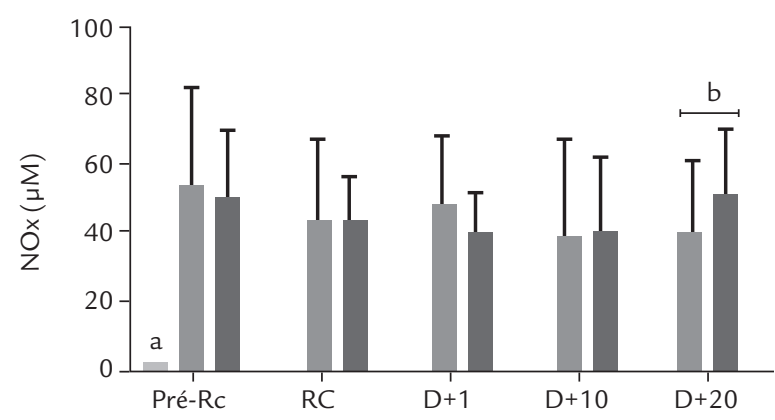

${ }^{\mathrm{a}} \mathrm{P}<0.05$ versus Myeloma and Lymphoma ${ }^{\mathrm{b}} \mathrm{p}<0.05$ versus Pre-CR

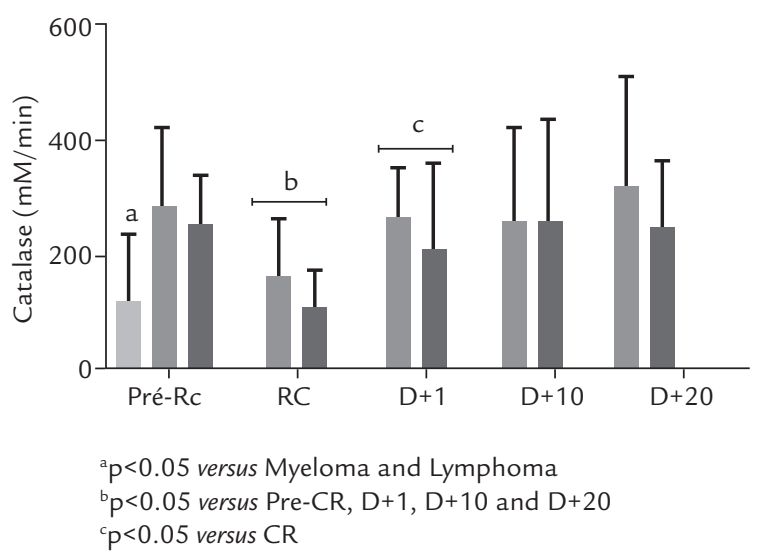

FIGURE 1. Profile of oxidative stress in patients with multiple myeloma $(n=17)$ and lymphomas $(n=20)$ submitted to HSCT. 
observed that the basal NOx levels were positively correlated with grafting time $(\mathrm{r}=0.4664, \mathrm{p}=0.032)$ (Figure 3$)$.

\section{Discussion}

The present study showed that patients with MM and Hodgkin's and non-Hodgkin lymphoma show a state of oxidative stress and conditions consistent with DNA damage, represented by high MDA and DI values, with reduced activity of SOD and CAT anti-oxidative enzymes when compared with the control group. This finding is consistent with several studies reporting that patients with hematological malignancies have a hyperoxidative state before any $\mathrm{CR}$, suggesting an intrinsic process of the underlying disease or inherent to drug treatments prior to $\mathrm{HSCT}^{11-17}$.

The CR with high-dose chemotherapy, to which the patients had been previously submitted, was able to exacerbate this hyperoxidative state. After HSCT, the evaluated parameters gradually improved until they were restored to similar levels to those seen at patients' baseline, corroborating data observed by Sabuncuoglu et. al (2012) ${ }^{17}$.

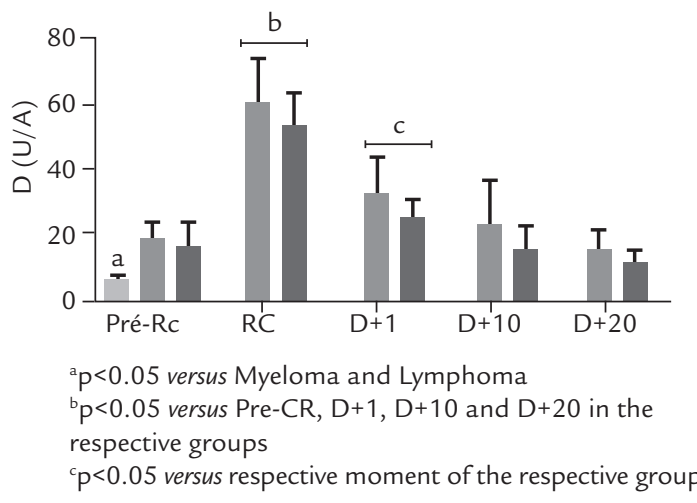

Control Myeloma Lymphoma

FIGURE 2. DNA damage index in patients with multiple myeloma $(n=17)$ and lymphomas $(n=20)$ submitted to HSCT.
In relation to DNA damage assessment, the results of this study corroborate and substantiate the oxidative stress profile at all times of the HSCT, considering that the excess of free radicals readily react with all components of the DNA molecule and can induce a permanent change in the genetic material ${ }^{18}$. Follow-up studies of the patients can be performed to correlate possible oxidative stress exacerbations with patient prognosis and survival, greatly contributing to the understanding of the oxidative process importance in patients undergoing HSCT.

The grafting time is an important indicator during the follow-up of transplanted patient, as it reflects the time of engraftment. The longer the grafting time, the higher is the risk of infections and other complications that can lead to death ${ }^{19}$. The positive correlations between DI and NOx with grafting time, as well as the negative correlation with Gpx, indicate the potential of these biomarkers as predictors of toxicity and grafting time in autologous HSCT in MM and Lymphomas. This study collaborates by giving rise to new studies with this approach and with a larger sample to reinforce the findings, aiming at the monitoring of patients and decreasing complications related to HSCT, demonstrating that the procedure brings significant changes in oxidative stress, as well as the treatment of the diseases discussed here.

\section{Conclusion}

The positive correlations of damage index and NOx with grafting time, as well as the negative correlation with Gpx, indicate the potential of these biomarkers as predictors of toxicity and grafting time in autologous HSCT in patients with MM and Lymphomas. These findings allow us to correlate the state of oxidative stress with possible DNA damage, showing evidence that the control of oxidative stress in HSCT could be associated with a less damaging condition for the patient and with a better prognosis, which may be verified by monitoring these patients after they are submitted to the autologous HSCT procedure.
Myeloma group

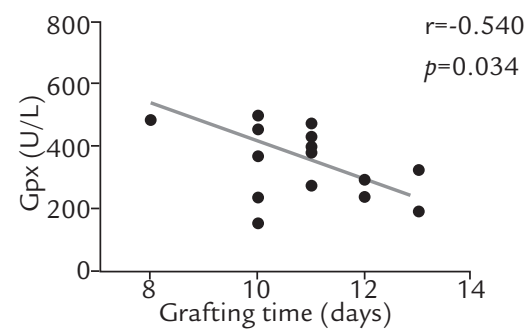

Myeloma group

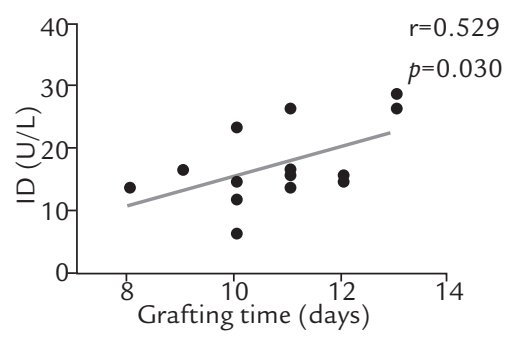

Lymphoma group

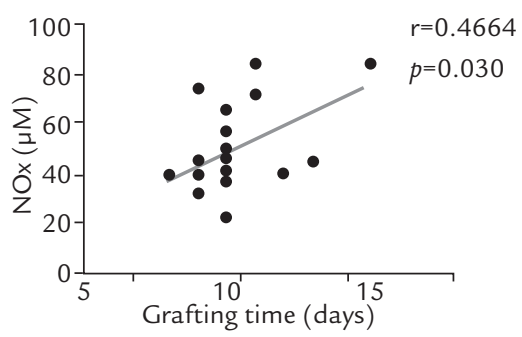

FIGURE 3. Analysis of correlation of oxidative stress and DI parameters at baseline (pre-CR) in patients with MM ( $\mathrm{n}=17$ ) and lymphomas $(n=20)$ submitted to HSCT. 


\section{Resumo}

Associação do estresse oxidativo e dano ao DNA com o tempo de enxertia em pacientes com mieloma múltiplo e linfomas submetidos a transplante autólogo de células-tronco hematopoéticas

O objetivo do estudo foi investigar a associação entre estresse oxidativo e dano ao DNA com o tempo de enxertia em pacientes submetidos ao transplante de células-tronco hematopoéticas autólogo (TCTH). Participaram do estudo 37 pacientes submetidos ao TCTH autólogo com diagnóstico de mieloma múltiplo (MM) e Linfomas (Hodgkin e não Hodgkin). Biomarcadores de estresse oxidativo e índice de dano ao DNA (ID) foram determinados no estado basal (Pré-RC) das doenças e durante o regime de condicionamento (RC), um dia após o TCTH, dez dias após o TCTH e vinte dias após o TCTH e no grupo controle composto por 30 individuos saudáveis. Os resultados demonstraram que os dois grupos de pacientes apresentaram um estado hiperoxidativo com elevado ID quando comparados ao estado basal e ao grupo controle e que o RC exacerbou essa condição. No entanto, após o tempo de acompanhamento do estudo, esse quadro foi reestabelecido ao estado basal de cada patologia. Os pacientes do estudo com MM apresentaram uma média do tempo de enxertia de 10,75 dias ( 8 a 13 dias), e de 10,15 dias ( 8 a 15 dias) para o grupo Linfoma. Nos pacientes com MM houve uma correlação negativa entre o tempo de enxertia e os níveis basais de $\mathrm{GPx}(\mathrm{r}=-0,54 ; p=0,034)$, indicando que níveis mais baixos de GPx estão relacionados a um maior tempo de enxertia, e para o ID, a correlação foi positiva $(\mathrm{r}=0,529 ; p=0,030)$. No grupo com Linfoma, observou-se que os níveis basais de NOx correlacionaram-se positivamente com o tempo de enxertia $(\mathrm{r}=0,4664 ; p=0,032)$. Os dados apontam para o potencial desses biomarcadores como preditores da toxicidade e do tempo de enxertia em pacientes com MM e Linfomas submetidos ao TCTH autólogo.
Palavras-chave: Transplante autólogo de células-tronco hematopoéticas; Estresse oxidativo; Dano ao DNA; Mieloma múltiplo; Linfoma.

\section{References}

1. Weij1 NI, Leton FJ, Osanto S. Free radicals and antioxidants in chemotherapyinduced toxicity. Cancer Treat Rev. 1997;23(3):209-40.

2. Sangeetha P, Das UN, Koratkar R, Suryaprabha P. Increase in free radical generation and lipid peroxidation following chemotherapy in patients with cancer. Free Radic Biol Med. 1990;8(1):15-9.

3. Dürken M, Agbenu J, Finckh B, Hübner C, Pichlmeier U, Zeller W, et al. Deteriorating free radical-trapping capacity and antioxidant status in plasma during bone marrow transplantion. Bone Marrow Transplant. 1995;15(5):757-62.

4. Knight JA. Free radicals: their history and current status in aging and disease. Ann Clin Lab Sci. 1998;28(6):331-46.

5. Evens AM, Mehta J, Gordon LI. Rust and corrosion in hematopoietic stem cell transplantation: the problem of iron and oxidative stress. Bone Marrow Transplant. 2004;34(7):561-71.

6. Apperley J, Carreras E, Gluckman E, Masszi T. EBMT-ESH Handbook on haematopoietic stem cell transplantation. $6^{\text {th }}$ ed. European School of Haematology; 2012. Available: https://ebmtonline.forumservice.net/.

7. Draper HH, HADLEY M. Malondialdehyde determination as index of lipid peroxidation. Methods Enzymol. 1990;186:421-31.

8. Green LC, Ruiz de Luzuriaga K, Wagner DA, Rand W, Istfan N, Young VR, et al. Nitrate biosynthesis in man. Proc Natl Acad Sci USA. 1981;78:7764-68. AEBI H. Catalase in vitro. Methods Enzymol 1984;105:121-6.

10. Singh NP, Mccoy MT, Tice RR, Schneider EL. A simple technique for quantitation of low levels of DNA damage in individual cells. Exp Cell Res. 1988;175(1):184-91.

11. Camargo CQ, Borges DS, Oliveira PF, Chagas TR, Del Moral JA, Durigon $\mathrm{GS}$, et al. Individuals with hematological malignancies before undergoing chemotherapy present oxidative stress parameters and acute phase proteins correlated with nutritional status. Nutr Cancer. 2015;67(3):463-71.

12. Imbesi S, Musolino C, Allegra A, Saija A, Morabito F, Calapai G, et al. Oxidative stress in oncohematologic diseases: an update. Expert Rev Hematol. 2013;6(3):317-25

13. Kasai H. DNA damage by oxygen radicals and carcinogenesis. Gan To Kagaku Ryoho. 1989;16(3 Pt 2):459-65

14. Al-Gayyar MMH, Eissa LA, Rabie AM, El-Gayar AM. Measurements of oxidative stress status and antioxidant activity in chronic leukaemia patients. J Pharm Pharmacol. 2007;59(3):409-17.

15. Oltra AM, Carbonell F, Tormos C, Iradi A, Saez GT. Antioxidant enzyme activities and the production of MDA and 8-oxo-dG in chronic lymphocytic leukemia. Free Radic Biol Med. 2001;30(11):1286-92.

16. Bartsch H, Nair J. Oxidative stress and lipid peroxidation-derived DNAlesions in inflammation driven carcinogenesis. Cancer Detect Prev. 2004;28(6):385-91.

17. Sabuncuoğlu S, Öztaş Y, Çetinkaya DU, Özgüneş N, Özgünes̨ H. Oxidative protein damage with carbonyl levels and nitrotyrosine expression after chemotherapy in bone marrow transplantation patients. Pharmacology. 2012;89(5-6):283-6

18. Valko M, Leibfritz D, Moncol J, Cronin M, Mazur M, Telser J. Free radicals and antioxidants in normal physiological functions and human disease. Int $\mathrm{J}$ Biochem Cell Biol. 2007;39(1):44-84.

19. Bayraktar UD, Nates JL. Intensive care outcomes in adult hematopoietic stem cell transplantation patients. World J Clin Oncol 2016;109(1):98-105. 